\title{
DESCRIPTIONS OF NEW GENERA AND SPECIES OF FISHES FROM JAPAN AND THE RIU KIU ISLANDS.
}

\author{
John OtTerbein SNyder, \\ of Stanford University, California.
}

This paper contains descriptions of 3 new genera and 23 new species of fishes from Japan and the Riu Kiu Islands. They were collected during the explorations of the United States Bureau of Fisheries steamer Albatross in the north Pacific Ocean and along the shores of Japan, in 1906.

\section{Family SYNGNATHIDA.}

\section{MICROPHIS EXTENSUS, new species.}

This species is closely related to M. pleurotænia of Hawaii. Two examples of the latter agree with Günther's description of the species and differ from Microphis extensus in both color and form. The Hawaiian species has the light bands very broad, thus confining the light area on the side of the body to the dorsolateral row of plates, and almost eliminating it from the breast and abdomen. The caudal fin is without spots, having a dusky center and an indefinite, broad, light edge. The ridges of the snout are smoother and the body is considerably broader and heavier. The caudal fin is much less acute. There are 24 to 25 dorsal rays in $M$. pleurotænia, while $M$. extensus has 21 or 22 .

Head 4.5 in length measured to base of caudal fin; depth 3.5 in head; depth caudal peduncle 7.5 ; snout 2 ; eye 4 ; interorbital space 9 ; D. 22 ; A. 4 ; rings $19+15$.

Two strongly denticulated ridges extend from snout to interorbital space; a dorsolateral denticulated ridge from tip of snout to orbital rim, which is also serrated; upper edge of opercle with a strong ridge from which many striæ radiate. Osseus rings of body with strong keels at the angles which have spines posteriorly, the spines growing larger on the tail; plates with only a trace of a median keel. Dorsal located on seven rings beginning with the sixteenth. Caudal fin pointed, the length contained about 1.4 times in the head. Pectoral broadly rounded, about 2 in snout; rays, 18. 
Color in alcohol deep brown; a white stripe extending along back srom tip of snout to base of caudal; chin with a white spot; throat, breast, and abdomen with a broad, white stripe, which is divided by a dark median area of the body color; caudal fin with two large, oval, white spots on its basal third and with two narrow stripes beyond these.

In life the color is deep purple, the light stripes being brilliant, orange red. The caudal is dark reddish brown, with bright orange spots; the edge of the fin white.

This description is of the type, Cat. No. 68226, U.S.N.M., a female specimen $47 \mathrm{~mm}$. long from Naha, Okinawa. Cotype, No. 21418, Stanford University collection.

The brood pouch of the male extends over fourteen osseus rings. It is connected with the anal opening by a furrow, the edges of which rise and merge into those of the brood pouch two rings in advance. There is a median keel on the breast anterior to the pouch.

Five specimens were secured measuring 28 to $48 \mathrm{~mm}$. in length. In swimming the movements are slow, the caudal is broadly expanded, and the brilliant colors stand out in bold contrast against the gray coral rocks of the pools.

\section{CORYTHROICHTHYS QUINQUARIUS, new species.}

Head 7.7 in length to base of caudal; depth 2.7 in head; snout 2; eye 9 ; interorbital width 12 ; D. 28 ; A. 4 ; rings $16+38$.

The head is long and slender, the slope from tip of snout to occiput interrupted by only a slight curve over the eyes; body deepest about midway between head and origin of dorsal fin. Head without spines or serrations; a median crest on upper part of snout, a dorsolateral one extending to nostril, a prominent supraorbital crest and a low occipital ridge; gill cover with a ridge which passes from orbit to its posterior third; plates of body without spines or keels; back flat; abdomen angular. Egg pouch extending over eighteen rings and including a little over half the tail. Dorsal fin located on six rings. Pectoral rays 17 , their length about 5 in head. Anal very small, with apparently four rays. Caudal slightly shorter than pectoral.

Color in spirits brownish; upper part of snout, chin, and throat whitish; a broad, dark band from snout to eye, several rows of small spots along side of snout, and a median dark line running backward from chin; opercle with a light stripe extending along and beyond the keel, and also a shorter, parallel one below it; sides of body with very small, pearly ocelli in quinqunx order, each with a brown dot in the center; back and tail variegated with brown and whitish; edge of pouch with white, dark-bordered bars; caudal narrowly tipped with white. 
Described from the single specimen, type Cat. No. 68227, U.S.N.M., from Tanegashima, Japan; length $123 \mathrm{~mm}$.

\section{Family RUVETTIDA.}

JORDANIDIA, new genus.

This genus is distinguished by the branched lateral line and the wholly degenerate ventral fins.

Body rather elongate and flat; a patch of small scales on posterior part of body; lateral line extending from upper edge of gill opening to near end of base of soft dorsal, with a branch originating below base of fifth dorsal spine, curving downward and backward and then passing in a straight line along median part of body to base of caudal fin; palatines with teeth; finlets 3 , the anterior of which is closely apposed to the preceding fin.

Tpye of genus.-Jordanidia raptoria, new species.

The genus is named for Dr. David Starr Jordan.

JORDANIDIA RAPTORIA, new species.

Head 3.3 in length to base of caudal; depth 5 ; depth caudal peduncle 6.5 in head; diameter eye 4 ; width interorbital space 6.5 ; length snout 2.6 ; D. XVIII, 14 ; A. 12.

The body is moderately elongate, deepest in the middle, the caudal peduncle compressed; head pointed, interorbital area concave, lower jaw projecting beyond the upper; maxillary extending slightly beyond anterior edge of pupil; eye large and round, midway between tip of snout and border of opercle. A single row of teeth on jaws and palatines; teeth of jaws large, knife-like, widely spaced; a group of three to five greatly enlarged fangs in anterior part of upper jaw; two small teeth at symphysis which project upward and backward beyond tip of snout. Pseudobranchiæ large. Gill-rakers numerous, minute, unequally developed.

Lateral line originating at upper edge of gill opening, bifurcating beneath base of fifth dorsal spine, the upper branch passing directly backward a short distance below base of dorsal and ending below base of soft dorsal; lower branch abruptly curving downward and extending along middle of body to base of caudal. Posterior part of body with small, thin scales which occupy an area of rather indefinite extent projecting from base of caudal forward as a wedge, the tip of which lies on the lateral line; other parts of body and head apparently smooth.

Spinous dorsal inserted just a little behind upper edge of gill opening and extending to a point opposite the vent; the longest spines about equal in length to diameter of eye. First dorsal rays longest, about three in head, the others successively shorter. Three finlets 
following the soft dorsal, the first more remote from the second than that is from the third and closely apposed to the soft dorsal. Anal inserted below soft dorsal, its rays somewhat shorter than those of the dorsal; followed by three finlets like those above. Caudal deeply forked, the upper lobe somewhat the longer, 1.5 in the head. Pectoral two in head. Ventrals absent, the ends of the small pelvic bones almost touching the surface on the median line beneath the bases of the pectorals. Vertebræ 31 ; cæca 7 .

Color in the preservative pale silvery, darker above especially on the opercles, upper margin of eye, interorbital space, tip of snout, lips, area beneath the maxillary and gill cavity. Spinous dorsal with a black spot between first and third spines; edge of fin black; posterior part of caudal dusky.

Type.-Cat. No. 68228, U.S.N.M., a specimen from the market at Kagoshima, measuring $250 \mathrm{~mm}$. in length. Cotype No. 21419, Stanford University collection.

Other specimens are similar to the type, not showing any marked amount of variation.

\section{Family PEMPHERIDA.}

\section{CATALUFA, nevv genus.}

This genus is distinguished from others of the family by the small, closely apposed, strongly ctenoid scales. It includes $C$. umbra, new species, which may stand as the type, and C. compressus of the Australian region.

CATALUFA UMBRA, new species.

Head 3.5 in length to base of caudal; depth 2.2 ; depth caudal peduncle 3.2 in head; eye 2.2 ; snout 6.5 ; maxillary 2 ; interorbital space 3.3 ; D. V, 12 ; A. III, 33; scales in lateral line 72 .

Eye very large, circular; interorbital space convex; snout blunt and rounded; lower jaw rather sharp at its tip and projecting; maxillary extending to point below center of pupil. Edge of preopercle covered with scales except on lower portion where it is denticulate, the angle being armed with an especially strong spine which projects downward and backward; head elsewhere completely scaled except on tip of snout and lips. Minute, brush-like teeth on jaws, vomer, and palatines. Gillrakers somewhat slender and longer than the fringes behind them; 8-21 on the first arch. Pseudobranchiæ well developed. Scales of body small, close set, rather heavy and strongly ctenoid; extending for a considerable distance out on the base of the caudal and forming a high sheath along base of anal where they are extremely minute; seventy-two series in a lateral line counting to base of caudal from where the pores extend to near the end of tail; 
eleven rows between origin of dorsal and lateral line; scales of head finer than those of body and less rough, a sharp line of demarkation between the two passing upward from the opercular opening and then curving far forward to a point midway between the eyes, thus allowing a sharply outlined, wedge-shaped area of the rougher body covering to extend forward over the nape and occiput to the interorbital area.

First branched ray of dorsal longest, 4 in the length; base of fin 5 in the length. Caudal forked, about 4 in the length. First anal spine short and easily overlooked; third spine strong; about half as long as the following ray; although damaged, the anal rays appear to be gradually shortened from the first to the last. Pectoral sharply rounded, 4 in the length. Ventral spine strong, the fin rounded, about 7 in the length.

Color in spirits rather pale bluish black, the head with a brownish tint; fins all dusky except the pectoral which is nearly immaculate; ventrals speckled; tips of dorsal, caudal, and anal blackish; base of caudal dark.

The species is represented by but one specimen which was collected by Mr. Aoki at Misaki. It measures $160 \mathrm{~mm}$. in length.

Type.-Cat. No. 68229, U.S.N.M.

\section{Family SERRANID瓜.}

\section{PSEUDANTHIAS VENATOR, new species.}

One specimen of a Pseudanthias, apparently new, was found in the Kagoshima market. It is distinguished by a pearly white bar which passes from snout beneath eye to lower edge of base of pectoral, a bow-shaped bar of same color extending from base of spinous dorsal to posterior end of base of anal, the filamentous fins, size of scales, and number of fin rays.

Head 4.3 in length to base of caudal; depth 2.8 ; depth caudal peduncle 2.2 in head; eye 4 ; snout 4.3 ; maxillary 2.1 ; D. X, 16; A. III, 7 ; scales in lateral series 40 ; pores in lateral line 44 .

Maxillary without supplemental bone; completely scaled; extending to a vertical through posterior border of pupil; the width of posterior end equal to length of snout. Edge of preopercle denticulate, the teeth largest just above the angle. Opercle with two large, flat spines, the upper at the angle being the larger. Mouth oblique: Lower jaw with a large canine near the symphysis, followed by a smaller one halfway back; also a band of minute teeth which narrows to a single row posteriorly Upper jaw with a large canine opposite and slightly behind the principal one of lower jaw; a second strong one entirely within the mouth on inner edge of maxillary, pointing $80796^{\circ}$-Proc.N.M.vol.40-11-34 
voL. 40 .

inward and backward; jaw covered with a band of fine teeth. Pseudobranchiæ large; gillrakers extremely long and slender, the ventral ones equal to diameter of eye; 11-24 on the first arch.

Curves of lateral line rather closely following the dorsal contour, and not abruptly bent at any point. Scales of body ctenoid; 6 rows above lateral line at its origin; 2.5 rows between lateral line and middle of spinous dorsal; 3.5 between lateral line and middle of soft dorsal; 14 between base of anal and lateral line.

The dorsal spines beyond the third are of about equal length, 3 times in head; rays about 1.9 in head, the last ones somewhat filamentous; base of soft dorsal with a low sheath of scales. Second and third anal spines contained 2.3 in head, the first not half as long; middle rays of fin slightly longer than head. Tips of both dorsal and anal extend beyond base of caudal. Caudal lunate, the upper and lower rays elongate and filamentous; extreme length of fin contained 2.5 in distance from tip of snout to base of caudal. Ventral acutely pointed; equal in length to caudal, reaching somewhat beyond base of third anal spine. Pectoral almost equal in length to head.

Color in the preservative pinkish with a bluish tinge; three yellowish, nearly parallel stripes extending from head backward and disappearing just before reaching caudal peduncle; a narrow, pearly white stripe extending from tip of snout beneath eye downward to lower edge of base of pectoral; a bow-shaped stripe of same color, though fainter, passing from middle of base of spinous dorsal downward and curving backward along base of anal; median line of abdomen with a dead white stripe; first gill arch with a very narrow, white stripe along base of filaments.

Type.-Cat. No. 68230, U.S.N.M., a specimen measuring 118 mm., from Kagoshima.

\section{Family LUTIANIDA.}

PLATYINIUS AMOENUS, new species.

This form resembles $P$. macrophthalmus of the Atlantic. It is somewhat more slender, has a more pointed snout, and differs in color.

Head 2.2 in the length to base of caudal; depth 2.9 ; depth caudal peduncle 3.2 in head; diameter of eye 3 ; length snout 3.2 ; width interorbital space 4.8 ; length maxillary 2.6 ; D. X, 11 ; A. III, 8; scales lateral line 62 ; between lateral line and origin of spinous dorsal 6 ; between lateral line and origin of anal 14 .

Dorsal outline rather more strongly curved than the ventral. Eye very large, located before middle of head, high up, the interorbital area extending but little above it; maxillary not quite reaching a point below middle of eye; interorbital area convex; the skull almost flat, with four ridges, the inner of which are separated by a 
rather wide, smooth space. Teeth of each jaw in a narrow, villiform band, outside of which is a row of small canines; villiform teeth on the palatines and vomer, the latter in a lunate patch; tongue naked. Pseudobranchiæ large; gill-rakers 5-9, the upper ones minute.

Head with a row of enlarged scales extending downward from posterior margin of eye to edge of maxillary; about six rows below this on the preopercle; border of preopercle naked, the edge finely serrated; opercle and subopercle scaled; occiput with two shields of coarse scales; head elsewhere naked; back with sixteen scales between occiput and insertion of dorsal; fins naked except the caudal, which has minute scales extending almost to the tips of the rays.

Third and fourth dorsal spines highest, about three in head; middle rays scarcely shorter, the posterior one somewhat elongate, the tip extending beyond edge of fin. First anal spine half the height of second, the latter about a fourth of its length shorter than the third, the length of which is contained 3.3 times in the head; anterior ray three in head, the others gradually shorter except the last which is similar to the last dorsal ray, neither dorsal nor anal reaching base of caudal when depressed. Caudal deeply forked, the lobes equal and pointed; 3.5 in the length. Pectoral very acutely pointed and slightly falcate, its tip extending to a vertical through origin of anal. Ventrals acute, 1.5 in head.

Color in spirits yellowish; a dark spot at upper edge of opercle, where it covers the lower part of a broken brown band which extends over the nape; a somewhat indefinite dark stripe having its origin about midway between nape and first dorsal spine extends along back below base of dorsal fin; a similar stripe, but less definite, extends along the side just above the lateral line to a point below end of dorsal, from where it passes upward and ends at base of caudal; scales above the pectoral with more or less dusky color.

The type, Cat. No. 68231, U.S.N.M., is a specimen $260 \mathrm{~mm}$. long, from the market at Naha, Okinawa. Another example, somewhat smaller but differing in no other way from the type, is in the Stanford University collection, cotype No. 21420.

\section{Family HEMULID瓜.}

\section{PENTAPUS FORMOSULUS, new species.}

An apparently new species is here described from one specimen found in the market at Naha, Okinawa. It resembles $P$. microdon, but it has a deeper body and a much smaller eye.

Head 3.6 in length to base of caudal; depth 3 ; depth caudal peduncle 9.3 ; eye 4 in head; snout 3 ; interorbital space $3 ; \mathrm{D} . \mathrm{X}, 9$; A. III, 7 ; scales in lateral series 45 ; between lateral line and spinous dorsal 2; between lateral line and base of anal 12 . 
Head pointed; mouth small, the maxillary extending to a point about midway between posterior nostril and border of eye. Teeth weak, in narrow bands on the jaws; the outer row enlarged; four small canines on upper jaw, two on the lower; lateral ones of upper jaw somewhat heavier than median pair. Edge of suborbital smooth, with a spine-like point below center of pupil; preopercle,smooth; opercle with a small, flat spine. Gill-rakers 5-6 on first arch; reduced to mere knobs. Snout naked; scales of head and body weakly ctenoid.

Third dorsal spine highest, 2.3 in head; the following ones slightly shorter; longest rays equal in height to third spine. Third anal spine slender, its length about 3 in head. Anal when depressed not extending so far posteriorly as the dorsal, neither dorsal nor anal reaching beyond middle of caudal peduncle when depressed. Caudal deeply cleft; lobes falcate, the upper longer than the lower, about 2.5 in the length. Pectoral rather acute, 1.3 in head. Outer ray of ventral long, reaching anal opening when the fin is depressed.

Color in spirits brownish yellow, darker above than below. There are indications of a broad, light stripe along side of body above base of pectoral, and also of a dark spot on opercle.

Type.-Cat. No. 68247, U.S.N.M., a specimen $222 \mathrm{~mm}$. long, from the market at Naha, Okinawa.

\section{Family SPARIDA.}

NEMIPTERUS BATHYBIUS, new species.

Three specimens of a Nemipterus that appears to be undescribed were bought in the market at Kagoshima. The width of the suborbital at the widest part is not over half the diameter of eye, the maxillary extends to a point below anterior edge of pupil, there are three or four canines on either side of upper jaw, the dorsal fin is filamentous, the last spine is highest, the upper lobe of the caudal falcate, the ventrals extend to the origin of anal, and there are 45 scales in the lateral line.

The species appears to be related to Nemipterus japonicus (Bloch.). When compared with specimens of the latter from Cavite, N. bathybius may be easily distinguished by the narrower preorbital which is deeply concave on its ventral edge.

Head 3.2 in length to base of caudal; depth 3.4 ; depth caudal peduncle 3 in head; eye 3.6 ; snout 3.2 ; maxillary 2.6 ; width interorbital space 4 ; D. X, 9 ; A. III, 7 ; scales in lateral line 45 ; between lateral line and base of dorsal 3 ; between lateral line and origin of anal, obliquely downward and backward 9 . 
The interorbital space is convex; the snout rather pointed; suborbital area narrow, the width contained about 2.2 times in longitudinal diameter of eye, the ventral edge with a deep and rather abrupt concavity near end of maxillary; the concavity together with the convex posterior edge giving the suborbital a distinctive form. Edge of preopercle smooth except for some very minute denticulations at its upper edge. Maxillary extending to anterior edge of pupil. Teeth of upper jaw villiform; an enlarged outer row with three or four canines on either side anteriorly; lower jaw with two rows of comparatively strong teeth anteriorly, a single row of enlarged teeth along the sides. Gillrakers short and stubby, 4-9 on the first arch. Opercle with three rows of scales.

Dorsal spines high, rather slender and acute, the membrane not incised between their tips; last three spines longest, about 2.4 in head; anterior rays equal in height to the preceding spines, the posterior ones somewhat longer. Second anal spine intermediate in height between the first and third, 7.5 in head; last ray 2.3 in head. Lower lobe of caudal pointed, 1.3 in head; upper lobe falcate, a little over twice as long as lower; edge of caudal deeply emarginate. Ventrals reaching origin of anal. Pectorals acutely pointed, equal in length to ventrals.

In life the body was bright silvery with a pinkish tinge and pearly reflections; a narrow lemon-yellow stripe extends from upper edge of axil to middle of caudal peduncle, a faint brassy stripe along base of dorsal, a wide red stripe above lateral line, lateral line bordered by a light stripe with pearly reflections, below which is a brassy stripe narrowly bordered by dark pink; head pinkish, the snout purple; chin, throat, breast, belly, and lower surface of tail bright lemon yellow; dorsal translucent, the edge yellowish orange; vermiculations of lemon on membrane of fin; caudal bright pink, the filamentous rays yellow, becoming orange toward tip, upper edge of fin orange; anal and ventrals translucent; pectorals pink.

In spirits the body is rather reddish above, plain silvery below, all the bright tints having disappeared and no indication of the stripes remaining.

Type.-Cat. No. 68232, U.S.N.M., a specimen $280 \mathrm{~mm}$. long including the caudal filament. Locality Kagoshima, Japan.

Two smaller examples, one of which has been placed in the Stanford University collection, cotype No. 214201, are like the type except that the ventrals are slightly shorter.

The stomach of each specimen is everted, indicating that it was taken in rather deep water. 


\section{Family POMACENTRIDE.}

\section{ABUDEFDUF RHOMALEUS, new species.}

Head 3.5 in length measured to base of caudal fin; depth 1.8 ; depth caudal peduncle 6 ; eye 4.2 in head; interorbital space 2.5 ; snout 3 ; D. XII, 15 ; A. II, 13 ; scales in lateral series 24 ; between lateral line and base of dorsal 2 ; between lateral line and origin of anal 10 .

The body is very deep, the ventral outline much more elevated than the dorsal; dorsal contour evenly curved on anterior half; ventral contour oblique and almost straight from chin to breast and nearly horizontal from the latter point to anal opening; head short and broad; eye very small, the diameter less than length of snout and equal to about half the width of interorbital space; mouth very small, oblique, the maxillary not reaching much over half way between tip of snout and border of eye. Teeth scarcely flattened, small, simple, fixed, closely apposed, in a single row. Gillrakers slender, the longest equal in length to about half the diameter of eye, 5-15 on first arch. Suborbital and preopercle with naked, smooth edges.

Scales weakly ctenoid; snout naked below and in front of nostrils; suborbital with one row of scales; preopercle with 3 ; opercle with 3 ; bases of dorsal, anal, and caudal with large scales above which minute ones extend outward on the membranes; lateral line with pores on 18 scales; each scale of the median row on caudal peduncle with a pit near the center.

Spines and rays of fins very strong; dorsal spines beyond the sixth of about equal height, 2 in head; soft dorsal rounded, the middle rays highest, reaching almost to middle of caudal when depressed, 1.2 in head. Cleft of caudal shallow, the lobes convex, the length equal to that of head. Second anal spine 2 in head; the fin rounded, 1.4 in head; Pectoral rounded, equal in length to head. Outer ray of ventral filamentous, the tip reaching anal opening when the fin is depressed.

Color in spirits, uniform deep brownish black.

Described from the type Cat. No. 68233, U.S.N.M., a specimen 165 $\mathrm{mm}$. long, from Naha, Okinawa. Another example, cotype No. 21422, Stanford University collection, is of equal size and does not appear to differ from the type except that there are 13 spines and 16 rays in the dorsal fin.

ABUDEFDUF CLARKI, new species.

Head 3.3 in length to base of caudal; depth 1.7 ; depth caudal peduncle 5.5 ; eye 2.5 in head; interorbital width 2.5 ; snout 3 ; D. XIII; A. II, 13 ; scales in lateral series 26 ; between lateral line and origin of spinous dorsal 4 ; between lateral line and origin of anal 9. 
Body markedly deep the dorsal and ventral contours evenly rounded, the dorsal more elevated than the ventral. Eye large, its longitudinal diameter greater than length of snout and about equal to distance between orbit and edge of opercle; interorbital area broad and convex. Suborbital and preopercle covered with scales, the edges smooth. Teeth simple, scarcely compressed, in a single row, closely apposed. Maxillary extending just beyond a vertical through anterior edge of pupil.

Lateral line discontinued beyond middle of soft dorsal; no pores on the caudal peduncle, but each scale in the median row with a minute pit. Scales of head and body denticulate; bases of dorsal and anal with a sheath of scales; membranes of dorsal, caudal, and anal with minute scales; snout naked.

Fourth, fifth, and sixth dorsal spines longest, 1.3 in head; soft dorsal and anal elevated, the dorsal rather pointed; height of fins about 1.2 in the head. Caudal deeply cleft, the lobes with acute tips. Pectoral pointed, its length a little less than that of head. Ventrals pointed, the tips filamentous, reaching base of second anal spine.

Color in spirits deep brown; a narrow, oblique, white band passing across body from base of ninth dorsal spine to origin of anal; upper edge of pectoral with a black spot which spreads downward and becomes diffuse over the base of fin.

This description is of the type, Cat. No. 68234, U.S.N.M., an example $70 \mathrm{~mm}$. long from a pool at Tanegashima. Three smaller specimens were collected at the same time, one of which is numbered 21423 cotype, in the Stanford University collection.

In young individuals the white band is somewhat more distinct, an occasional example showing it very sharply outlined, and also followed by a second which is separated from the first by about four scales.

A few young specimens were found in the pools at Misaki. Other examples of the species were earlier identified by Jordan and Snyder as Chrysiptera melas. They differ from that form in having the light, oblique band, the sharply pointed caudal lobes, and the black spot at the base of pectoral. For like reasons this species can not be identified with Glyphisodon violaceus Brevoort.

The species is named for Mr. Austin Hobart Clark.

\section{Family OSTRACIIDA.}

LACTOPHRYS TRITROPIS, new species.

This species differs from others known to the Japanese fauna in having the carapace three angled. It differs from 0 . concatenatus ${ }^{1}$ in the strong spines of the dorsal and lateral ridges. It does not 
appear to be identical with any Atlantic form. It has been compared with the young of $O$. gibbosus Linnæus and found to differ in that the latter has a four or five angled carapace.

Carapace distinctly three angled, the greatly elevated dorsal ridge surmounted by two distinct, flat spines; two suborbital spines; four spines on the lateral ridge, one of which is beneath the eye, one below the dorsal, two closely apposed and located on anterior half of ridge; ventral surface convex in the middle, the lateral ridges projecting rather strongly downward; snout pointed, a slight knob near its tip, 1.6 times diameter of eye, four in length to base of caudal; carapace broadly closed both above and below the tail. D. 9 ; A. 9; P. 10; C. 10 .

Color in the preservative, yellowish; each facet of the sides of carapace narrowly outlined in black and with a dark center; caudal peduncle with a few oblong, dark spots.

Three specimens from Misaki, measuring about $75 \mathrm{~mm}$. long, show no important individual variation. A much smaller specimen from the Tokyo market, collected by Prof. K. Otaki, has the spines relatively longer and stronger than the others.

Type.-Cat. No.68235, U.S.N.M., Misaki,Japan. Cotype, No. 21424, Stanford University collection.

\section{Family SCORPAENID瓜.}

SEBASTODES TANAK $Æ$, new species.

A dark colored species of Sebastodes characterized by short gillrakers, concave interorbital space, well-developed preopercular, postocular, and tympanic spines, prominent parietal spines and ridges, and a very long, naked maxillary is represented by a single specimen from Hakodate.

Head 2.6 in length to base of caudal; depth 2.7; depth caudal peduncle 3.4 in head; eye 4.8 ; snout 4 ; maxillary 2.2 ; width interorbital space 6.1 ; D. XIII, 13; A. III, 7; pores in lateral line 34.

Nasal, preocular, postocular, and tympanic spines present, each of which is heavy and high, but not very acute; postocular spine preceded by a strong ridge; parietal ridges high, each with a low posterior spine; preorbital with a broad, flat, triangular spine; preopercle with three well-developed spines which are close together and directed backward; below these are two low, rounded processes. Opercular spines, two, broad and flat, the lower one nearly covered with scales. Two humeral spines, the upper of which is short and acute, the lower broad and flat, its tip serrated. Eye of moderate size, its diameter somewhat greater than width of interorbital space. Interorbital area flat, the high spines and ridges above eye making it appear concave; a narrow trough in the middle formed by two low frontal ridges which diverge somewhat posteriorly, as do also the 
rows of spines and the parietal ridges. Length of maxillary three times as great as width of interorbital space, reaching well beyond a vertical through posterior edge of orbit. Jaws even, the lower one without a prominent symphyseal knob. Teeth very fine; in broad patches on jaws, vomer, and palatines. Gillrakers $7-14$; short and rather broad; all but two on the upper arch and four or five on the lower being little more than mere rounded knobs.

Fifth dorsal spine highest, its length contained a little less than two times in head; the spines from the third to the seventh but little shorter; longest rays about 2.2 in the head, reaching base of caudal when depressed. Second anal spine slightly higher than third and considerably stronger, its length contained three times in head; longest rays 1.8. Pectoral rays 18 , half of which are simple; depressed fin reaching a vertical through anal opening. Ventral spines 3 in head; rays 13; fin pointed, not reaching anus. Caudal obtusely rounded, 1.6 in head.

Body with scales that are weakly ctenoid, a thick epidermal covering causing them to appear smooth; about 15 oblique series above lateral line and 45 below; many small supplemental scales, often 10 or more covering the base of a single large scale. Head crowded with small, weakly ctenoid scales which are also supplied with supplemental scales. Snout and region anterior to preopercular spines, preorbital, maxillaries, mandible, chin, throat, and branchiostegal region naked. Spinous dorsal naked. Other fins with minute scales that extend almost out to the tips of the rays.

Color in spirits deep, dark brown, obscurely mottled; traces of a light band extending along back beneath the dorsal fin. Peritoneum inside of mouth and gill chamber light.

One specimen, type, Cat. No. 68236, U.S.N.M., about $290 \mathrm{~mm}$. long, from Hakodate, Japan.

\section{Family COTTID无.}

\section{COTTUS NOZAW $Æ$, new species.}

Cottus nozawæ is distinguished from other Japanese species of the genus by the following combination of characters: Three preopercular spines, naked palatines, four ventral rays, and a very short maxillary which reaches to anterior border of eye and not beyond anterior border of pupil.

Head 3.2 in length to base of caudal; depth 4.5; depth caudal peduncle 3.2 in head; snout 3.2 ; eye 3.6 ; interorbital space 7 ; maxillary 2.7 ; D. VIII, 17 ; A. 13; P. 15; pores in lateral line about 30.

Body moderately robust, the head short, snout blunt; interorbital area and occiput convex; maxillary not quite reaching pupil; anterior nostril with a low tube, the posterior one with a scarcely evident rim; 
preopercle with a long, slender, curved spine at its upper edge; two smaller spines below this pointing downward and forward; a sharp spine on lower edge of opercle; nasal spines not evident, palatines naked; vomer with a small patch of weak teeth. Lateral line complete. Minute prickles covering a small area beneath pectoral; other parts of body naked and smooth. Dorsals entirely separate, the membrane of spinous dorsal just reaching base of first ray; middle spines highest, 3 in head; longest rays about 2.3. Anal rays about 2.8; both dorsal and anal falling far short of caudal when depressed. Ventral rays I, 4, not reaching vent. Pectorals reaching a vertical through base of first anal ray.

Color light below, clouded with dusky above; four more or less definite saddle-like spots on back; two below spinous dorsal and two below soft dorsal; a narrow, dark band on base of caudal; rays and spines of fins with rows of dark spots.

Type.-Cat. No. 68237, U.S.N.M., a specimen $85 \mathrm{~mm}$. long, from the Ishikari at Sapporo. Cotype, No. 21425, Stanford University collection.

Named for Prof. Sunziro Nozawa.

MYOXOCEPHALUS YESOENSIS, new species.

One specimen of a Myoxocephalus obtained at Hakodate does not appear to belong to a known species. It is characterized by a short, robust body without plates or scales except along the lateral line, short snout and small eyes, verrucose skin on upper parts of head where the ridges are very low, short postorbital and occipital tentacles, and two short preopercular spines. An almost colorless chin and throat and the short spines distinguishes it from $M$. stelleri, and the small eyes alone will prevent it from being confused with $M$. nivosus. It appears to most closely resemble $M$. brandti. It has, however, a smaller eye, the longitudinal diameter being considerably shorter than the snout and equal to the width of interorbital space. The upper preopercular spine is shorter and there are no small plates below the lateral line.

Head 2.4 in length to base of caudal; depth 3.5 ; depth of caudal peduncle 5 in head; eye 5.6 ; snout 3.5 ; interorbital space 5.6 ; maxillary 2.2 ; D. IX, 13 ; A. 10 ; P. 17 ; pores in lateral line 34 .

Skin on upper parts warty; very short postocular and occipital filaments; postocular region with short, digitate ridges, some of which approach the median line while others extend bąckward and unite with an uneven, low ridge which extends from posterior border of eye, along occiput to nape where it breaks up into minute forks; a second ridge parallel with and a-little below the occipital ridge passes backward and after one or two interruptions becomes continuous with the humeral spine; interorbital stay with a bony surface; upper 
parts of opercle with a bony ridge continuous with the short, blunt spine; nasal spines short and very sharp; preopercle with three spines, the upper of which is somewhat shorter than longitudinal diameter of eye, the second not half so long, the third very short, blunt, and projecting downward. Interorbital space concave; occipital region flat between the ridges; lower jaw included; maxillary extending to posterior edge of orbit.

Skin naked except along lateral line where-each pore opens beneath a small, concealed scale. Dorsal spines very slender, the longest (fourth and fifth) contained about 3.2 times in length of head; tip of each with a short villus; longest rays contained about 3.2 times in length of head. Anal scarcely higher than spinous dorsal, the rays of neither anal nor dorsal reaching base of caudal when depressed. Pectoral 1.5 in head; ventrals 2 in head.

Head clouded with dusky above; a poorly defined dark spot extending from eye along snout; a second less evident spot between eye and maxillary; lower lip with dusky spots, the chin and throat immaculate; back with two indefinite, dark bands which extend upward on the spinous dorsal; similar bands below the soft dorsal, the posterior part of the last one being definitely outlined, the fin with oblique, dusky clouds; anal with three broad, oblique, dark bands; posterior half of caudal peduncle and base of anal with a sharply outlined cross-band with irregular edges; posterior half of caudal with broad, blackish reticulations.

Type.-Cat. No. 68238, U.S.N.M., measures $175 \mathrm{~mm}$. in length. Locality, Hakodate market.

OCYNECTES MODESTUS, new species.

This species differs from Ocynectes maschalis in the absence of occipital tentacles and in its plain color. Also the snout is more pointed, the maxillary shorter, the eye smaller, the body deeper, and there is one more ray in the dorsal fin.

Head 3.4 in the length to base of caudal; depth 3.9 ; depth of caudal peduncle 9 ; eye 5 in head; snout 3.5 ; maxillary 3.2 ; interorbital space 4.7 ; D. IX, 14 ; A. 11 ; P. 14 ; pores in lateral line 35.

Head and body as in $O$. maschatis, though slightly deeper, the dorsal contour being a little more elevated and the snout more pointed. Above each eye is a broad flap, the posterior edge of which bears a row of seven or more tentacles, the whole resembling a coarse-toothed comb. Nasal spines prominent, embedded in a thick, fleshy covering, each with a slender tentacle at its tip; anterior nostrils with low rims; posterior nostrils with large tubes located immediately behind the nasal spines; a low, fleshy ridge extending from between nostrils along interorbital area, growing lower and disappearing at a point between orbital flaps; head otherwise perfectly smooth 
and without tentacles; body perfectly smooth; lateral line complete; pores large, the anterior nine with tentacles which are simple, bifid or trifid. Preopercular spine long, simple, and with a perceptible upward curve. Mouth small; maxillary extending to a vertical passing between anterior edge of orbit and pupil. Teeth in broad bands on jaws, vomer, and palatines.

Dorsals separate; outline of spinous dorsal slightly concave, the length of highest (anterior) spines contained about 2.3 times in the head; all but the last three anal rays large and fieshy, the membrane deeply incised between them; height of longest anal rays 2.5 in head; last dorsal ray connected by membrane with caudal peduncle, the last anal ray free posteriorly; both dorsal and anal falling far short of base of caudal when depressed. Tip of pectoral reaching a vertical through base of first anal ray when depressed; lower seven pectoral rays fleshy, the membrane deeply incised between them; all the rays simple. Ventrals 2 in head, not reaching anal opening. Caudal rounded; 1.4 in head.

In spirits the color is almost plain, a faint dusky band being suggested below the spinous dorsal, and two similar ones below the soft dorsal; tentacles of the lateral line black; orbital flap dusky. Spinous dorsal dusky, with two indistinctly outlined light spots; soft dorsal with about seven oblique, dusky bars; anal with similar bars which are broader and more numerous; upper and lower rays of caudal with four or five elongate, dark spots which are faintly continued as bars on the fin. Pectorals with narrow, irregular, dusky bars. Ventrals immaculate. Head with a narrow, dark line curving from tip of snout beneath nostril and passing backward below eye; another beginning at posterior margin of eye and extending across preopercle to base of spine.

Type.-Cat. No. 68240, U.S.N.M., from Same, Japan. A cotype, No. 21426, Stanford University collection, is like the type in all particulars except that there are 15 dorsal rays and no tentacles at tips of nasal spines. The cotype is also from Same.

BERO ZANCLUS, new species.

This species differs from Bero elegans in having a markedly slender body and no multifid tentacles on the head, there being a pair of slightly fringed flaps above the eyes and but one pair of small, simple tentacles on the occiput. The intromittent organ is much smaller and more slender in B. zanclus.

Head 2.8 in length to base of caudal; depth 5.8 ; depth of caudal peduncle 13.5 ; eye 4.5 in head; maxillary 2.1 ; snout 3.9 ; interorbital space 15 ; D. IX, 15 ; A. 15 ; P. 15 ; pores in lateral line 38.

Body elongate, tapering gradually from head to caudal peduncle; snout rather pointed; lower jaw included; eye large, the diameter about equal to length of snout; maxillary extending to a point below 
posterior edge of orbit. Bands of minute teeth on jaws, vomer, and palatines. Preopercular spine equal in length to half the diameter of eye, broad, very flat, and strongly curved upward, the greater part of it concealed beneath the skin; nasal spines well developed. Anterior nostril with a long tube; posterior nostril with a high rim located behind nasal spine. A slender tentacle on maxillary near its posterior edge; a rather broad, pointed flap above upper, posterior margin of eye, and a pair of minute tentacles on occiput. Anterior part of lateral line with a row of thirteen small, scale-like plates, below which is a row of seven somewhat larger ones, the exposed edges of which are denticulate; head and body smooth elsewhere. Four very large mucous pores on each side of lower jaw ; lateral line with a slight double curve anteriorly, bending downward from upper edge of gill opening, and then swinging upward somewhat above its general level. Anal papilla slender and pointed, its length equal to half the diameter of eye.

Dorsal fins separate, the spines slender and flexible, the highest contained 2.5 times in length of head; highest dorsal rays 2.3 in head. Origin of anal below second dorsal ray; highest ray 3 in head. Caudal slightly rounded posteriorly, 16 in head. Pectoral pointed, the tip reaching a vertical through base of third anal ray. Ventrals with two weak rays; 3.3 in head.

In the preserved specimen the head and body are spotted and mottled with dark brown, the pattern being very intricate; dorsals, anal, and caudal with broad, oblique, and rather indefinite dark bars; pectoral with a dark blotch near its base and three or four irregular bars beyond this.

The species is described from a single specimen measuring $88 \mathrm{~mm}$. in length, found in the market at Otaru, Japan.

Type.-Cat. No. 68239, U.S.N.M.

Family AGONIDE.

PODOTHECUS XYSTES, new species.

A specimen of Podothecus collected at Nagaoka, Japan, by Mr. M. Nakamura, appears to belong to an unknown species, which is characterized principally by its long anal fin. It appears to be related to $P$. siurioides (Guichenot), but that form has a shorter anal, ten rays, and it also differs in color and other particulars. In many respects this species resembles the young of Draciscus, and possibly it should be placed in that genus. It differs from D. sachi Jordan and Snyder in having a shorter and broader snout, larger eye, fewer barbels, and in having fewer dorsal and anal rays.

Head 3.6 in the length to base of caudal; depth at nape 7.6; snout 2.2 in head; eye 4.2 ; interorbital space 4.6 ; length maxillary 3.5 ; D. IX, 9 ; A. 15; lateral line 41 . 
The depth at the nape is equal to the length of snout; the width of head measured between the crests of the subopercular ridges is slightly greater than length of snout. The tip of the snout is injured, but there appears to have been two terminal spines, each of which is followed by a short lateral spine, and these in turn followed by a series of very narrow, slightly diverging, rugose ridges, several of which converge and unite at the bases of a pair of closely apposed spines, which are a little nearer eye than tip of snout. Other ridges pass backward and end just above the tubular nostril, while others more ventrally located pass backward along the edges of lower jaw. Orbital crest arched somewhat above contour of head, with a strong spine on its upper posterior part; interorbital space broadly concave; the lateral ridges well separated. Occiput with two parallel crests, each ending in a high, flat spine which is similar to the succeeding ones on the nape and body; surface of the occipital region between the crests concave and smooth. On the orbital margin, below and posterior to the larger spine is a smaller spine marking the anterior end of a curved ridge which passes backward and ends at a point directly above gill opening. Lower rim of orbit with a row of fine denticulations. Side of snout with a prominent ridge ending in a spine below posterior margin of pupil; a small spine on snout above the ridge. Lower border of preopercle with a pronounced ridge; subopercle with two ridges, the upper much higher and sharper, both ending in flat, blunt spines. Mouth broad, the maxillary extending to a point beneath anterior margin of eye. A group of four or five barbels on each side beneath tip of snout; posterior edge of maxillary with a group of about ten barbels, the posterior pair of which are much longer than the others; lower lip with a pair of small barbels near the middle on each side; none at the symphysis. Each angle of the body armed with a row of strong spines as is usual in the genus. Plates with radial striæ.

Spinous dorsal inserted just behind the fourth row of dorsal plates, the base including the membrane extending over ten of them; one row between the spinous and soft dorsal; soft dorsal located on twelve rows. First dorsal spine highest, 2.5 in the head; the others graduated in length to the last which about equals the diameter of pupil; longest (first) dorsal ray 2 in head. Origin of anal just posterior to a vertical through base of last dorsal spine; the middle rays longest, 2 in head. Caudal 1.7 in head, the margin slightly concave. Upper pectoral rays longest, 1.25 in head; the succeeding rays shorter until the fourth from below which is elongate, the following 3 in turn growing shorter; the 5 lower rays somewhat thickened, the membrane deeply scalloped between their tips. Ventral rays 2, their length contained 3.3 in the head. 
Snout with a black bar on each side extending from tip to eye; tip of snout black beneath; three indefinitely outlined dark blotches on opercular region; a dark, transverse bar on occiput including the spines and extending to the lateral ridge; a similar bar on nape crossing the second row of body rings; body with a number of elongate, blackish spots located mostly above the lateral line; basal region of pectoral with an oval, black spot; axil of fin dusky; dorsals and caudal bordered with blackish.

Type.-Cat. No. 20702, Stanford University collection, a specimen measuring $190 \mathrm{~mm}$. long from Nagaoka, Japan. Mr. M. Nakamura, collector.

Family TRIGLID E.

\section{LEPIDOTRIGLA KISHINOUYI, new species.}

This species is characterized by the possession of a rather long, emarginate, armed snout, unmarked dorsal with evenly graduated spines, moderately long, free pectoral rays, and a dark colored pectoral fin with elongate white spots.

Head measured to edge of opercle 2.9 in length to base of dorsal; depth 4.1; depth caudal peduncle 5.5 in head; snout (eye to base of spine) 2.2 ; eye 3.4 ; interorbital space 4.8 ; D. IX, 13 ; A. 15 ; scales in lateral series about 60 .

From the median line outward the edge of the snout grows more serrate to the large spine at the angle, the length of which is contained three times in the width of the interorbital space. Upper outline of snout almost straight; somewhat concave in one example; interorbital area deeply concave; two supraorbital, one opercular, one occipital and one scapular spine present; plates of head rugose, a little rougher than in allied species; a furrow behind eye which does not extend across occiput; No teeth on vomer and palatines. Seven slender gillrakers present on lower limb of first arch.

Third dorsal spine slightly longer than second, 1.8 in head; its tip and those of succeeding ones reaching an equal distance (origin of soft dorsal) posteriorly when depressed; anterior edges of spines serrated, the median row of serrations strongest on first spine; longest dorsal rays 2.5 in head. Edge of caudal concave; length of fin 1.4 in head. Tips of anal and dorsal rays reaching an equal distance posteriorly when depressed. Pectorals reaching an eye's diameter beyond origin of anal; longest detached ray falling short of tip of ventral a distance equal to one-third the diameter of eye. Ventrals reaching base of third anal ray. Dorsal fins inserted in a groove each edge of which is bordered by a row of spinous scales, those along base of soft dorsal being stronger and sharply pointed. Other scales of body heavy and roughly ctenoid: 
Alcoholic specimens have the throat, breast, and outer or anterior surface of pectorals, except the tips, dead white; inner surface of pectorals dusky, the color not extending over the lower attached rays, which are white; lower half of fin dense black with elongate, white spots; rays white near tip of fin. Caudal with two indistinct, vertical, dusky bands.

Type.-Cat. No. 68241, U.S.N.M., a specimen measuring $98 \mathrm{~mm}$. in length, from Kagoshima. Two other specimens, one of which is deposited in the Stanford University collection, cotype, No. 21427, are from the same locality and do not differ from the type.

The species is named for Dr. K. Kishinouye.

Family GOBIID龙.

CLARIGER EXILIS, new species.

This species differs from Clariger cosmurus in having the body more extensively scaled, the scales extending forward over an angular region to or beyond the base of spinous dorsal. The body is more slender and the dark lateral stripe is broader, extending downward and almost covering the sides of the body.

Head 4 in length to base of caudal; depth 8 ; depth caudal peduncle 8.5 ; eye 6 in head; snout 3.6 ; interorbital space 5.5 ; D. III, 11 ; A. $11 ;$ P. 18 .

The head is broad, much wider than the body and considerably depressed; snout short, the eyes located far forward and directed obliquely upward; interorbital space flat; mouth broad, the cleft extending backward to a point beneath pupil; lower jaw projecting somewhat; tongue broad and deeply notched anteriorly. Teeth in narrow bands on the jaws; a well defined outer and inner row of enlarged teeth on the upper jaw; an inner row of slightly enlarged teeth on the lower jaw, the teeth increasing in size posteriorly, the last on each side separated from the others and considerably enlarged. Vomer and palatines naked. Gill clefts restricted to the sides, the openings somewhat broader than the base of pectorals. The skin of the head is full and wrinkled about the snout and chin; a row of four or five fleshy barbels below eye; a pair of broad, short flaps at the symphysis.

Head and greater part of body naked; caudal peduncle completely scaled except on the upper and lower edges, the scaled area extending forward in an irregular patch, the point of which reaches to or beyond a vertical through the spinous dorsal. Spinous dorsal short and low, the first spine inserted about midway between occiput and origin of soft dorsal; the first two spines closely apposed; the entire fin very frail. Bases of soft dorsal and anal of about equal length, the membranes rather thin and tha rays frail; no membrane 
posterior to the last ray. Caudal broadly rounded. Pectoral somewhat acutely rounded. Ventrals united; free posteriorly.

Color much like that of $C$. cosmurus; the lateral stripe light brown and much broader, extending downward so that the entire sides are covered; sides with many scattered white spots of various sizes; a number of larger ones about equal to diameter of pupil, located in a row near upper edge of dark area; a large light spot on upper and also on lower edge of caudal peduncle; upper part of snout, head and back whitish; throat and abdomen light; base of pectoral and central portion of caudal dark.

Type.-Cat. No. 68242, U.S.N.M., measuring about $32 \mathrm{~mm}$. in length. Locality, Tanegashima, Japan. Cotype No. 21428. Stanford University collection. Ten specimens from Tanegashima range in size from 20 to $32 \mathrm{~mm}$. in length. They were found in the more outlying pools and appeared only after the water had been thoroughly poisoned.

\section{Family CALLIONYMIDÆ.}

\section{DRACULO, new genus.}

In this genus the spinous dorsal is absent; the preopercular spine has three or four strong branches or prongs; the lateral line is single. The body is broad and flat, skin of head smooth, mouth small, teeth in narrow bands, lower lip fringed, gill rakers short and few.

Type of genus.-Draculo mirabilis, new species.

DRACULO MIRABILIS, new species.

Head (tip of snout to end of opercular flap) 2.9 in length to base of caudal; depth 6.6 ; width of body 4.5 ; length of snout 4.5 in head; diameter of eye 5 ; width interobital space 10; D. 14; A. 13; P. 18.

The body is broad and flat, the head triangular when viewed from above, the tail rather abruptly compressed behind the body; caudal peduncle deep; dorsal contour but little curved between tip of snout and base of caudal. Skin of head thin and smooth. Anterior nostril with a tube or elevated rim. Mouth small, the maxillary not reaching eye; lower lip with a fringe of long papillæ. Teeth minute, in narrow bands on the jaws; none on palatines and vomer. Gill openings very narrow; pseudo-branchiæ present, the filaments long; gillrakers short and widely spaced, seven on first arch. Preopercle with a large, four-pronged spine. Opercular flap extending to base of pectoral. A small anal papilla present.

Lateral line extending from occiput to base of caudal fin; an abrupt downward curve occurring near middle of body; with large pores and short branches at intervals; a branch passing over caudal peduncle and connecting with line on opposite side; a transverse, connecting $80796^{\circ}$-Proc.N.M.vol.40-11-35 
branch extending across occiput; two accessory branches on head, one of which is beneath the eye, the other extending downward to edge of opercle.

No spinous dorsal present. Soft dorsal and anal inserted on a vertical passing just posterior to anal opening and decidedly nearer tip of snout than base of caudal; the middle rays of both fins nearly equal in height, about three in head; the posterior rays of anal growing longer posteriorly so that they reach slightly beyond base of caudal when depressed. Caudal pointed, the length contained about 1.5 times in length of head. Pectoral pointed, 1.25 in head, the tip reaching beyond origins of dorsal and anal. Posterior rays of ventral longest, two in head.

In alcohol, pale flesh color, finely marbled and speckled with brown; immaculate beneath; dorsal, caudal, and upper pectoral rays spotted with brown.

The species is represented by three specimens measuring $35 \mathrm{~mm}$. in length. They were found entangled in a great seine drawn by fishermen on the sandy beach near Tomakomai in Hokkaido, at the request of Prof. S. Nozawa.

Type.-Cat. No. 68243, U.S.N.M. Cotype No. 21429, Stanford University collection.

\section{Family PLEURONECTIDA.}

\section{HIPPOGLOSSOIDES KATAKURA, new species.}

This species may be distinguished from H. dubius, H. elassodon, and $H$. hamiltoni by the more abrupt and higher arch in the lateral line, there being six or seven rows of scales between its uppermost part and the horizontal; by the deeper body, the dorsal contour being accordingly more arched. There are more rays in the dorsal fin of $K$. katakuræ, it having 90, while the other closely related species have not more than 85 . The ventral fins of the new species are pointed, and the dorsal originates slightly in front of the eye.

Head 3.8 in length to base of caudal; depth 2.5; depth of caudal peduncle 9 ; eye 4.7 in head; snout 5.5 ; maxillary 2.5 ; D. 90 ; A. 69 ; pores in lateral line 93 ; transverse series of scales 100 .

Body dextral; dorsal contour rather strongly arched from a point above the eye, thus giving the anterior parts a more obtuse appearance than is common to other Japanese species of the genus. The upper eye is placed well in advance of the lower; the interorbital space rather broad, with four rows of minute scales at its narrowest part. Maxillary extending to a vertical passing midway between posterior edge of eye and pupil. Teeth small, slender, in a single row on the symphysis, where they are irregularly placed, enlarged and somewhat canine-like. Gillrakers long, flat, and rather slender, $3+12$ on the first arch. Vertebræ 41. 
Scales finely ctenoid except in the abdominal region, where they appear to be cycloid; those of blind side somewhat smoother than the others. No plates or rough surfaces on head or other parts. Eyes naked. Fin rays with minute scales, the membranes naked. Lateral line arched though not abruptly so, the curve being gentle and even, about 30 scales long and 7 above a horizontal at its highest part; straight from curve to tip of caudal.

Dorsal inserted on the blind side at a point directly opposite anterior edge of orbit, the fin reaching the median line at base of third ray; rays highest beyond median part of fin, about 2.3 in the head. Anal preceded by a strong spine which protrudes through the skin; base of fin extending anteriorly a slight distance beyond that of dorsal; highest rays of anal contained 2.3 in head. Caudal obtusely rounded, 1.2 in head. Pectoral with 11 rays, the third, fourth, and fifth from above, longest; two in head; that of blind side with 10 rays, the fifth and sixth longest, 2.3 in the head. Ventrals symmetrical, the fifth ray from before longest, 3 in head.

Color in spirits plain pale brown.

One specimen, the type, Cat. No. 68244, U.S.N.M., measuring 320 mm. in length. Locality, Otaru, Japan.

The type was presented along with specimens of other species by Mr. Kenkichi Katakura, for whom the form is named.

\section{LEPIDOPSETTA MOCHIGAREI, new species.}

Two specimens of a species closely related to Lepidopsetta bilineata were collected at Otaru in Hokkaido. They belong to a form which evidently represents $L$. bilineata, but differ in having a much narrower interorbital width, larger eyes, blunter snout, and smoother scales. In number of fin rays and size of scales the Otaru species also differs materially from specimens of $L$. bilineata from Nikolski and from Alaska. The former has 74 to 80 rays in the dorsal, 57 to 61 in the anal, and 92 to 98 scales in the lateral line, as shown by two specimens. Five specimens of $L$. bilineata from three localities have fin rays and scales as follows:

$\begin{array}{lrrr}\text { Nikolski, Bering Island........ D. } 75-79 ; & \text { A. } 58-62 ; & \text { L. L. } 83-90 . \\ \text { Chignik Bay, Alaska............ } & 72-76 ; & 57-58 ; & 78-83 . \\ \text { Seattle, Puget Sound........... } & 68-75 ; & 50-58 ; & 79-89 .\end{array}$

Head 3.8 in length to base of caudal; depth 1.9; depth of caudal peduncle 9.2 ; eye 3 in head; snout 5.5 ; maxillary 4 ; D. 80 ; A. 61 ; pores in lateral line 98 ; in transverse series of scales 90.

Body apparently somewhat deeper than in L. bilineata, the dorsal contour rising somewhat abruptly, and the snout having a less pointed appearance. Orbits very large, the upper being considerably larger than the lower; anterior edge of the lower in advance of the upper. Interorbital area high and very narrow. Maxillary extending 
to anterior border of pupil of lower eye. Teeth small, conical, closely apposed; strong on the blind side, very weak and few on the opposite side; located in a single row with occasionally an irregular one. Gillrakers on first arch $2+5$; those on upper limb scarcely evident, the lower ones short, flat, blunt, and widely spaced. Nostrils tubular.

Lateral line with a very abrupt arch which at its highest point is about eight scales above the horizontal, with an accessory branch which does not extend backward as far as the gill opening. A conspicuous ventral branch extends downward and forward beneath the eye to the maxillary. Scales weakly ctenoid, this character appearing as distinctive when the species is compared with $L$. bilineata; those of opercles minute and closely crowded; occipital space with but a single row of minute scales; all the fin rays except the pectoral on the blind side with minute scales; edge of preopercle naked.

Dorsal originating above anterior edge of pupil; longest rays contained about two times in head. Highest anal rays equal in length to those of dorsal. Caudal rounded, 1.2 in the head. Pectoral 1.8 in head; that of blind side about 3 in head. Ventrals rather stout, the rays heavy, 3 in head. Base of anal preceded by a short, strong spine that protrudes through the skin.

Color in spirits pale brown.

Two specimens were procured in the market at Otaru, Hokkaido, one of which, measuring $208 \mathrm{~mm}$. in length, is selected as the type, Cat. No. 68245, U.S.N.M. The other, measuring $145 \mathrm{~mm}$., is recorded in the Stanford University collection as cotype No. 21430.

(Mochigarei, a Japanese name, meaning rice-cake flounder.)

\section{GLYPTOCEPHALUS SASÆ, new species.}

This species has a deeper and more robust body than G. zachirus, and it also differs from that species in having a shorter, rounded pectoral and a much weaker anal spine, which does not appear to protrude from the skin. It differs markedly from $G$. zachirus and also from $G$. cynoglossus, the Atlantic form, in having but 49 vertebræ.

Head 4.8 in length to base of caudal; depth 2.9 ; depth caudal peduncle 11.5 ; eye 3.5 in head; snout 4.1 ; maxillary 5.2 ; D. 90; A. 77 ; pores in lateral line about 109 ; transverse series of scales about 113 .

Body dextral, the snout rather blunt; mouth small; the maxillary extending but little beyond anterior margin of eye, that of the blind side almost a third longer. Lower eye advanced in position, its posterior border touching a perpendicular through edge of pupil of upper eye; interorbital space broad, almost equal in width to half the vertical diameter of lower eye. Anterior nostril with a short tube. Teeth present on both sides of the jaws, in a single row, closely 
apposed, short, rather stubby, though incisor-like, the cutting edges somewhat granular and brown in color. Gillrakers 48, very short, pointed, and widely spaced. Bones of blind side of head very cavernous, four large pits in the preopercle being very distinct.

Dorsal inserted on the median line, the first ray rising from a point directly above middle of pupil; highest rays contained about 1.9 times in the head. Anal spine minute, concealed beneath the skin; longest anal rays 2 in head. Caudal obtusely rounded, somewhat shorter than head. Pectoral rays 11, the fourth and fifth from above longest, 1.3 in head. Pectoral of blind side 2.5 in head. Ventrals 3 and 3.6 in head, respectively.

Lateral line almost straight, the anterior part with a slight elevation.

Scales small, cycloid, well imbricated, covering the preopercular margin and the interorbital area, but not intruding on the skin of the eyes; extending outward to near the tips of the rays of the unpaired fins; basal parts of rays of unpaired fins scaly; snout naked on the right side, almost entirely scaled on the blind side.

Color in spirits deep brown, the dorsal, anal, and caudal somewhat darker along their edges; pectoral of eyed side broadly bordered with blackish.

Described from the type, Cat. No. 68246, U.S.N.M., a specimen 350 $\mathrm{mm}$. long from the market at Otaru, Hokkaido. This specimen was secured through the courtesy of Mr. Shigeho Sasa, for whom the species is named. Two other examples were secured from a mass of partly decayed fishes at Mororan. One is large, dark colored, and similar to the type. The other is much smaller and very light in color, except for the dark edges of the fins. In these the dorsal has 85-84 rays; anal 74-77 rays; pores in lateral line 112-106. One of the Mororan specimens is retained in the Stanford University collection as cotype No. 21431. 


\section{$2 \mathrm{BHL}$ Biodiversity Heritage Library}

Snyder, John Otterbein. 1911. "Descriptions of new genera and species of fishes from Japan and the Riu Kiu Islands." Proceedings of the United States National Museum 40(1836), 525-549.

https://doi.org/10.5479/si.00963801.1836.525.

View This Item Online: https://www.biodiversitylibrary.org/item/53820

DOI: https://doi.org/10.5479/si.00963801.1836.525

Permalink: https://www.biodiversitylibrary.org/partpdf/53293

\section{Holding Institution}

Smithsonian Libraries

\section{Sponsored by}

Smithsonian

\section{Copyright \& Reuse}

Copyright Status: Public domain. The BHL considers that this work is no longer under copyright protection.

This document was created from content at the Biodiversity Heritage Library, the world's largest open access digital library for biodiversity literature and archives. Visit BHL at https://www.biodiversitylibrary.org. 